\title{
Displaced sentential complements to nouns in German
}

\author{
ANDREAS BLÜMEL \\ University of Göttingen, Göttingen, Germany \\ ablueme@gwdg.de
}

\begin{abstract}
This article makes the novel observation that in German, CPs functioning as complements to nouns can appear to the left of their associated DP-internal gap position. It surveys the phenomenon and, based on a number of diagnostics, argues that the noun complement clause exhibits properties as if its surface position is movement-derived. Based on parallel observations in PP-extraction from DP, I show that the same constraints on movement apply modulo construction-specific properties of DPs with a noun complement clause. The findings buttress previous approaches to extraction from DPs that highlight differentiating and controlling lexical factors. Given the delicacy of the judgments involved in this phenomenon, the article is mostly devoted to laying out its descriptive properties. Tentative suggestions as to an analysis are offered in the end.
\end{abstract}

Keywords: German, extraction from DPs, Complex-DP Constraint, Specificity Condition, $\bar{A}$-dependency

\section{Résumé}

Cet article fait la nouvelle constatation qu'en allemand, les SC fonctionnant comme des compléments de nom peuvent apparaître à la gauche de la position de leur trou syntaxique associé, à l'interne d'un SD. Il examine ce phénomène et, en partant d'un certain nombre de diagnostics, soutient que le SC complément du nom présente des propriétés indiquant que sa position de surface a été dérivée du mouvement. À partir d'observations parallèles dans l'extraction des SP des SD, je démontre que les mêmes contraintes sur le mouvement s'appliquent modulo les propriétés spécifiques à la construction des SD avec un complément de nom SC. Les résultats étayent les approches précédentes d'extraction à partir des SD qui mettent en évidence la différenciation et le contrôle par des facteurs lexicaux. Compte tenu de la

Parts of the material in this article were presented at the German linguistics colloquium at Göttingen University, the Nominals at the Interfaces Workshop at Sogang University in 2018 as well as the Incontro di Grammatica Generativa at the Università degli Studi di Padova in 2019. For comments and suggestions I am grateful to the audiences of these events. I also wish to thank three anonymous reviewers as well as Michael Barrie for his patience and support. 
délicatesse des jugements impliqués dans ce phénomène, l'article est surtout consacré à l'élaboration de ses propriétés descriptives. Des suggestions provisoires quant à une analyse sont proposées à la fin.

Mots-clés: allemand, extraction à partir des SD, Contrainte sur les SD Complexes, Condition de spécificité, A-dépendance

\section{INTRODUCTION}

The overall goal of this article is to contribute to a comprehensive picture of phenomena which give the impression of being instances of extraction from DPs in German. Particularly, it reports on a phenomenon where a subordinated clause appears discontinuously from a $\mathrm{DP}^{1}$ it is semantically associated with, as indicated by the gap $e$ shown in (1).

(1) Dass er incompetent sei, hat sie [die Behauptung $e$ ] gemacht. that he incompetent be had she the claim made 'She made the claim that he is incompetent.'

The phenomenon exhibits an obvious resemblance to sentences with a complex DP with a clausal complement.

(2) Sie hat [die Behauptung dass er incompetent sei] gemacht. she has the claim that he incompetent be made

'She made the claim that he is incompetent.'

This article investigates mostly syntactic and a few semantic properties of (1) and tentatively argues that the construction exhibits properties suggesting that it derives from its contiguous counterpart (2) by movement of the clausal unit out of the DP. The argumentation is tentative because the judgments on the constructions were not uncontroversial.

The logic of the argumentation will for the most part consist in showing that the extraction of a noun complement clause (NCC) from DPs strikingly parallels the better described - and yet elusive - cases of PP-extraction from DPs. ${ }^{2}$

(3) Über Windpocken hat Julia ein Buch gelesen. over chickenpox has Julia a book read 'Julia read a book about chickenpox.'

\footnotetext{
${ }^{1}$ Throughout, I will assume without argument the DP-hypothesis, see Abney (1987) et seq, which is by no means innocuous. I refer the reader to Van Eynde (2006), Bruening (2009), and Bruening et al. (2018) for a number of problems, as well as to Lieb (2005), Chomsky (2007), Georgi and Müller (2010), and in particular to Oishi (2015) for alternatives. As far as I am concerned, all constraints on syntactic displacement which this article refers to remain to be understood, that is, be derived in a principled fashion. Neither an NP-based view nor the DPhypothesis has the ingredients to derive them while at the same time meeting the austere conditions on postulating syntactic machinery formulated in Chomsky 2004 et seq. The choice of using DP in this article is little more than descriptive convenience.

${ }^{2}$ Abreviations: CDPC: Complex DP constraint; NCC: noun complement clause; NPI: Negative polarity items; PTCL: particle.
} 
I show that the phenomenon obeys most generalizations on movement out of complex DPs and to a limited extent exhibits connectivity effects. That said, NCCextraction challenges a few of the generalizations that have become standard repertoire in investigating extraction from DPs. For example, all examples violate the Specificity Condition (see Chomsky 1973) and furthermore suggest that the ban on extracting adjuncts should be replaced by a more nuanced view, namely that (at least some) adjuncts can be extracted as long as functionally, they behave as arguments to nouns. The findings of this article thus highlight lessons emphasized by Davies and Dubinsky (2003): While established restrictions on extraction from DPs are in dire need of explanation, so are factors that enter into lifting these restrictions.

This article is structured as follows: Section 2 provides some background on PPextraction from DPs, established restrictions, and analytical approaches, illustrated mostly with German and English. Honing in on German, the section demarcates PP-extraction from DPs from some two other phenomena falling under the rubric "discontinuous DPs", and shows how and why they deserve a differential treatment, while NCC-extraction should be treated on a par with PP-extraction. Section 3 outlines first descriptive properties of NCC-extraction and argues that the dependency should be captured in terms of syntactic movement, that is, as a dependency between an antecedent and its trace. Section 4 then corroborates the conclusion from section 3 by running various diagnostics well-established from PP-extraction from DPs. Section 5 tentatively touches on analytical options of NCC-extraction from DP. Section 6 concludes.

\section{BACKGROUND}

This section lays out some necessary background on PP-extraction from DPs and its conditions and restrictions. Building on what is knows about PP-extraction, I will subsequently show that these restrictions are operative in NCC-extraction in German as well, for the most part.

\subsection{The phenomenon of extraction from DPs}

The Complex DP-constraint (CDPC), of which (4) is one anachronistic formulation, was coined by Ross (1967: 70) ${ }^{3}$ to capture the fact that displacement of an XP is illicit once the XP's trace is contained in a complex DP.

(4) The Complex DP-constraint

Elements dominated by a sequence which is dominated by a determiner phrase cannot be questioned or relativized.

Example (5) illustrates the constraint by way of wH-extracting a PP from a complex DP. I will refer to this option as PP-extraction from DPs. Example (6)

${ }^{3}$ Credited to Edward Klima. 
shows the constraint at work with $\bar{A}$-extraction from a relativized DP. Rule (4) successfully captures both.

(5) *About what did John $\{$ destroy/stack $\}$ [a book $e]$ ?

(6) *The man about who I read [a statement which was about $e$ ] is sick.

It was recognized very early that certain contexts annul the constraint, such as the type of embedding verb. Thus, for example, verbs of creation like write contribute to forming the bridge needed for $\bar{A}$-extraction. Likewise, verbs which render the semantics of the embedded noun abstract (like read or edit), as opposed to concrete (like destroy or stack in (5)), have a similar ameliorating effect. This is illustrated in (7).

(7) About what did John $\{$ read/edit/buy $\}$ [a book $e]$ ?

The CDPC appears to be too strong, given that the right type of embedding verb appears to lift the constraint. Some ingenuity has flown into solving this problem, as I will elaborate later. The CDPC is a first descriptive approximation to the many factors that enter into the complex phenomenon "extraction from DPs". The semantic relationship between the embedding verbs and the complement nouns is in any event one of the aspects that awaits a satisfying solution. The factor is operative in NCC-extraction in German, too.

The Subject Condition (Chomsky 1973: 250) is another familiar constraint on displacement: while extraction from object-DPs is fine, subject-DPs disallow extraction out of them. ${ }^{4}$

(8) a. Who is the class reading a book about?

b. *Who is [a book about $e$ ] being read by the class?

(Davies and Dubinsky 2003: 36)

(9) a. [Of which car] did they find [the driver $e]$ ?

b. *[Of which car] did [the driver $e$ ] cause a scandal?

(Chomsky 2008: 36)

Again, as will become clear later, NCC-extraction in German is also subject to this condition.

Finally, an important restriction is that no extraction may take place from definite or specific DPs, as (10) shows (Fiengo and Higginbotham 1981, Davies and Dubinsky 2003, Simonenko 2015).

(10) *Who did Ashley read \{the/that/Bill's $\}$ book about?

All these mentioned restrictions are subject to many complications. For example, (9a) bluntly violates the Specificity Condition illustrated by (10), as do all examples of NCC-extraction from DPs in German - the topic of this article. So while it is an important research topic to understand the grammatical factors

\footnotetext{
${ }^{4}$ Modulo many complications, see Davies and Dubinsky (2003), Gallego and Uriagereka (2006), Chomsky (2008), inter alia.
} 
that underly contrasts like the one between (7) and (10), it should be kept in mind that there are counterexamples like (9a). A close look is needed at the types of nouns involved, and arguably, a differentiation between specificity and definiteness might pave a way to a better understanding of these issues. It is the modest goal of this article to make a contribution at the observational and, maybe, the descriptive level.

\subsection{A demarcation}

To properly delineate the empirical scope of this article, this passage briefly indicates that for German, at least three constructions involving discontinuous DPs must be distinguished. Only PP-extraction from DPs (a German specimen is given in (11)) will serve as the backdrop for description of NCC-extraction from DPs; the two other construction mentioned here have no obvious bearing on the diagnostics and the analysis of NCC-extraction from DPs.

(11) Worüber hast $\mathrm{Du}$ ein Buch gelesen?

where-over have you a book read

'What did you read a book about?'

By and large, German exhibits the same restrictions as English when it comes to PP-extraction from DPs.

The second phenomenon involving a discontinuous DP is the was-für-split (see, e.g., Pafel 1996; Leu 2008, 2015, and references therein), which features an invariant wH-pronoun was 'what', which can optionally split off the associated DP (12a) or pied-pipe it (12b).

(12) a. Was hast $\mathrm{Du}$ [e für ein Buch] gelesen? what have you for a book read

b. Was für ein Buch hast Du gelesen? what for a book have you read

'What kind of book did you read?'

The was-für-split should be kept distinct from PP-extraction from DP, since the two exhibit a number of important structural differences: In the was-für-split, the launching site of $\overline{\mathrm{A}}$-extraction is the left edge of the DP, as indicated by the $e$ in (12a), not the postnominal region. This indicates that the was-für-split involves extraction of a specifier (Pafel 1996) or extraction from a specifier (Leu 2008, 2015), not a complement of the noun, which is arguably the case with PP-extraction from DPs (as in (11)). Moreover, there are no restrictions with respect to the embedding verb. Thus, (13) are all possible, while the counterparts with PP-extraction from DPs are sharply out (14).

(13) Was hast $\mathrm{Du}$ für ein Buch \{verloren/verbrannt/vergessen\}? what have you for a book lost/burnt/forgotten 'What kind of book did you \{loose/burn/forget\}?'

(14) *Worüber hast $\mathrm{Du}$ ein Buch \{verloren/verbrannt/vergessen $\}$ ? where-over have you a book lost/burnt/forgotten 
A commonality between the two is the fact that PP-extraction from DPs is licit in indefinite contexts and impossible in definite ones, as (15) shows. ${ }^{5}$
*Worüber hast Du \{Marias/das/dieses\}
Buch where-over have you Mary's/the/that
book read

The was-für-construction is inherently indefinite, that is, there is no definite counterpart, with or without split.

Let me finally address a construction featuring what looks like a discontinuous DP, so-called split topics (see Ott 2011 and references therein).

(16) Studierende sind heute einige erschienen.

students were today some appear

'As for students, many showed up today.'

Like the was-für-construction and unlike PP-extraction from DPs, split topics exhibit no sensitivity to embedding verbs. Moreover, it seems as if they defy the Subject Condition, as the acceptability of (16) suggests, in contrast to both other constructions (see Jurka et al. 2011 on was-für). Finally, notice that split topics are perfectly acceptable with definite DPs, again, in contradistinction to PP-extraction from DPs and was-für-split.

(17) Studierende sind heute bloss diese erschienen. students were today merely these appear

'As for students, only these showed up today.'

There are other commonalities between these discontinuous DP-constructions, such as the fact that they all involve $\bar{A}$-movement, as evidenced by connectivity effects, sensitivity to so-called island constraints and the like. ${ }^{6}$ That said, the following summarizes important differences, which suggest that these should not be analyzed on a par.

(18) a. The was-für-split and split topics do not exhibit sensitivity to embedding verbs, that is, they are freely available independent of the verb that embeds them. This is not the case with PP-extraction from DPs. This means that crucially, the specific semantic relationship between the selecting verb and the noun in PP-extraction must be part of any analysis, and correspondingly has figured in all analyses up to date.

\footnotetext{
${ }^{5}$ Again, it should be kept in mind that certain exceptions exist. For example, extraction from DPs involving possessors are fine if the latter are bound by a local subject (cf. Davies and Dubinsky 2003, Huang 2018).

(i) Worüber hast Du Deine Diss geschrieben? where-over have you your dissertation written 'What did you write your PhD-thesis about?'

I will return to the point in section 5.2.

${ }^{6}$ Contexts that do not allow extraction of this type are known as island. Connectivity effects are (often morphological or syntactic) indications of an XP's base-position, where that XP surfaces in a displaced position.
} 
b. Contrary to appearances, split topics involve obligatory movement, as Ott (2011) argues at length, while was-für-split or PP-extraction from DPs are clearly optional. Evidence for this claim comes from numerous cases in which split topics cannot surface continuously and force movement of the topic-DP.

c. Relatedly, the was-für-split or PP-extraction from DPs plausibly involve a single DP and instances of subextraction from that DP, while split topics are likely to involve two nominal structures, as Ott persuasively shows.

d. The was-für-split or PP-extraction from DPs involves prima facie violations of island constraints (CDPC and Left Branch Extraction respectively), while if Ott (2011) is right, split topics do not.

I ask the reader to bear in mind these important differences. NCC-extraction from DPs in German has many aspects in common only with PP-extraction from DPs, as will be shown later in the article, and should be analyzed along the same lines.

\subsection{Treatments of the verb classes}

Let me briefly sketch different analytical approaches to account for the sensitivity to verbs involved in PP-extraction from DPs.

Early treatments of PP-extraction from DPs take the CDPC as an inviolable constraint. In the context of verbs in which a PP originating from a DP can evade the latter, these approaches had to employ mechanisms that circumvent violations. Particularly, rebracketing rules like (19) were invoked for this class of verbs (Bach and Horn 1976: 280, Cattell 1976, Chomsky 1977).

(19) $\left[{ }_{V P} \mathrm{~V}\left[{ }_{D P} \mathrm{~N}\right.\right.$ PP $\left.]\right] \rightarrow\left[{ }_{V P} \mathrm{~V}\right.$ DP PP $]$

The effect of the application of the rule is that upon rebracketing, no CDPC-violation is incurred when the PP undergoes movement. This rule was said to apply for a restricted set of verbs - those that can give rise to PP-extraction from DPs. Verbs like destroy, stack and the like do not trigger the rebracketing rule; as a consequence, PP-movement incurs a CDPC-violation.

Empirical evidence for such a rule was given in Chomsky 1977: 113-114. He noted that with the relevant class of verbs, ambiguities like (20) arise.

(20) They published their first book about Kafka.

a. They have published other books before, but this one is the first that has Kafka as its subject. (first $>$ PP)

b. They didn't publish any books before and the first book they ever published happened to be about Kafka. (first $\not>\mathrm{PP}$ )

That is, the PP can scope below or above the adjective first. In terms of the rebracketing rule, one might say that the low scope reading of the PP follows from a stage in the derivation before rebracketing, and the hight scope reading of the PP arises after rebracketing. The same ambiguity does not arise with other types of verbs as (21) shows. 
(21) They destroyed their first book about Kafka.

They have destroyed other books before, but this one is the first that has Kafka as its subject. (first $>$ PP)

This follows immediately, if the rebracketing rule is unavailable with the relevant class of verbs.

A quite different approach is taken in various works by Gereon Müller. He pursues the intuition that PP-extraction from DPs is contingent on the formation of a 'natural predicate'. For example, book reading, but not book forgetting, involves the formation of a natural predicate. Technically, he cast this intuition into different types of implementations. Following Baker (1988), Müller (1995) suggests that with the relevant class of verbs, the embedding verb and the noun are coindexed at surface structure such that the noun undergoes abstract incorporation at the level of Logical Form, LF.

(22) $\left[{ }_{V P} \mathrm{~V}_{i}\left[{ }_{N P} \mathrm{~N}_{i}\right.\right.$ PP ] $] \rightarrow$ LF: $\left[{ }_{V P} \mathrm{~N}_{i}+\mathrm{V}_{i}\left[{ }_{N P} t\right.\right.$ PP $\left.]\right]$

As the noun incorporates into the verb at LF, the barrier status of the NP is voided. When this happens, PP-extraction from DPs becomes possible. In Müller 2010: 47-50 that same intuition is reformulated in terms of AGREE (avoiding possible problems of look-ahead afflicting the abstract incorporation approach). Müller (1995) makes the intriguing suggestion that the ability to PP-extract from DPs correlates with the option of forming the corresponding $\mathrm{N}-\mathrm{V}$ compounds in German, cf. Vortraghalten ('talk-giving') vs. *Vortragvergessen ('talk-forgetting'); see (23). The verb class problem is thus shifted to the availability of morphological forms.

(23) Worüber hat Einstein einen Vortrag \{gehalten/*vergessen\}? where about has Einstein a take held/forgotten

While the intuition is not without problems, ${ }^{7}$ it is a recurring theme which should not be carelessly dismissed.

\footnotetext{
${ }^{7}$ The fact that the compound Bücherverbrennen 'book-burning' has gained sad notoriety might lead to the expectation that PP-extraction is licit, which is not the case.

(i) *Worüber haben die Nazis Bücher verbrannt? where about have the Nazis books burnt Intended: 'What are topics of the books which the Nazis burnt?'

Such mismatches might indicate that the suggested correlation should be formulated in a unidirectional way.

An anonymous reviewer notes that the English counterpart of (i) becomes licit to him/her, given the right context, say, a 'Fahrenheit 451' context. Likewise, the right context renders examples like (21) ambiguous, according to the reviewer. The observation suggests an approach along the lines of De Kuthy (2001), who adopts the 'qualia structure' approach to lexical semantics by Pustejovky (1995). She notes:

The idea of such an approach to semantics is to provide a model of meaning in language that "captures the means by which words can assume a potentially infinite number of senses in context while limiting the number of senses actually stored in the lexicon" (Pustejovsky 1995: 105). To account for this polymorphic behaviour of language, a set of generative devices (such as type coercion or co-composition) connect the different levels of lexical semantics, providing for the compositional interpretation of words in context.
} 
As a final note, German freely allows DPs to front independently of their PP-dependant.

(24) Ein Buch hat Fritz über Bienen gelesen.

a book has Fritz about bees read

'Fritz read a book about bees.'

Given the right types of verbs, it thus seems as if these DPs can form a constituent to the exclusion of the PP. Such facts have given rise to either remnant movement analyses (see Müller 1998) or operations that deliver independent DP- and PPconstituents (De Kuthy 2002).

\section{NCC-EXTRACTION FROM DPS}

This article is about a phenomenon which I have dubbed NCC-extraction, repeated here as (25) and supplemented with (26).

(25) Dass er inkompetent sei, hat sie [die Behauptung $e$ ] gemacht. that he incompetent be had she the claim made 'She made the claim that he is incompetent.' finite V-final clause

(26) a. ?Nach Afrika zu reisen hat er [das Angebot $e$ ] in Erwägung gezogen. to Africa to travel had he the offer in consideration pulled 'She took the offer to travel to Africa into consideration.'

b. Dass wir so verfahren sollten, war sie [der Ansicht $e$ ]. that we so proceed should was she the opinion 'She held that we should proceed this way.'

c. Franziska ist recht verstimmt, habe ich den Eindruck. F. is quite upset have I the impression

'I have the impression that Franziska is quite upset.'

I indicate the associated canonical position of the NCC with an $e$, leaving in abeyance, for the moment, the nature of the relationship of the dislocated $\mathrm{CP}$ and this gap. Based on various diagnostics, I will argue that this relationship must be characterized as a movement dependency, hence the term NCC-extraction. ${ }^{8}$

\footnotetext{
It strikes me as plausible to assume that it is pragmatic coercion which renders such examples acceptable or ambiguous. A structure which is syntactically transparent might be superimposed on the string by the parser, facilitated by pragmatic coercion. The syntactically opaque structure, which underlies (i) and its unacceptable English counterpart gives rise to the default reading.

${ }^{8}$ The comma after the displaced finite NCC in (26b) follows the orthographic convention of placing a comma behind a finite clause in the prefield. There is no requirement to insert a prosodic break behind the NCC.
} 


\subsection{Preliminaries}

To the best of my knowledge, there is no previous study on NCC-extraction. A fair number of speakers utter and accept this construction, which I have exclusively witnessed in colloquial German. That is, I have not been able to obtain written instances in corpora. Among the speakers I consulted, some consider such sentences awkward or degraded. Yet all speakers agree with respect to the relative acceptability presented here, that is, all consider the starred examples significantly worse than the baseline sentences. Other speakers consider the construction outright ungrammatical, and any analysis or explanation should address this split in acceptability judgments. As a disclaimer, all judgments of NCC-extraction are to be considered highly idealized; needless to say, they represent relative judgments.

The mentioned gap in the text corpora might be due to the special information structural import of the construction, where the dislocated CP seems to mark the discourse-relevant topic, and the containing main clause is backgrounded, often representing given information or information less relevant to the discourse theme. The fronted CP is commonly a contrastive topic, or contains a contrastive topic. What is - descriptively speaking - the containing main clause gives the impression of an afterthought needed to grammatically complete the actual point of interest, the dislocated CP. In written language such arrangement is either unlikely to occur or might occur in chat exchanges at best.

I found a single mention of the impossibility of extracting NCCs in De Kuthy 2002: fn. 7. She dismisses the phenomenon outright, claiming that "[s]eparating a verbal [sic] complement from its nominal head always results in ungrammaticality", based on and backed by examples like (27) - where (27a) is a fronted non-finite NCC and (27b) a fronted finite NCC.

a. *Nach Afrika zu reisen hat er das Angebot abgelehnt.
to Africa to travel had he the offer down-turned
'He declined the offer to travel to Africa.'
b. *Dass er inkompetent sei, hat er die Behauptung zurückgewiesen.
that he incompetent be had he the claim rejected
Intended: 'He rebutted the claim that he was incompetent.'

The examples (27) are indeed ungrammatical. However, these examples involve negative embedding verbs, on which I will have more to say below. The contrast between $(25) /(26)$ and (27) is noticeable, striking, and reminiscent of what was observed before regarding the sensitivity to selecting verbs in PP-extraction from DPs (recall the minimal pair (5)/(7)). In fact, the contrast seems to be identical, modulo the choices and availability of nouns and verbs that enter into forming a "semantically close" relationship.

\subsection{Descriptive properties}

Let me begin the descriptive survey by noting that NCC-extraction applies to various clause types so long as they can function as NCC in situ, that is, there is no principled restriction with respect to clause type. For example, while there is a restriction for 
verb second (V2) clauses to function as NCCs (roughly, the clause has to have intensional semantics), this restriction carries over to NCC-extraction. To survey the various clause types entering into NCC-extraction, I am presenting them side by side with their in situ or extraposed counterparts in the (b)-examples below.

The example (28a) involves a displaced V2-clausal complement, (29a) and (30a) are displaced non-finite clausal complements to nouns, and (31a) is a polar question complement to a noun, again, surfacing discontinuously from its associated noun Frage 'question'.

(28) a. Wir sollten so verfahren, war sie der Ansicht. we should so proceed was she the opinion

b. Sie war der Ansicht, wir sollten so verfahren. she was the opinion we should so proceed 'She was of the opinion that we should proceed this way.'

V2 clause

(29) a. So verfahren zu müssen, war sie der Ansicht. so proceed to must was she the opinion

b. Sie war der Ansicht so verfahren zu müssen. she was the opinion so proceed to must 'She was of the opinion that we should proceed this way.'

non-finite clause

(30) a. ?Nach Afrika zu reisen hat er das Angebot angenommen. to Africa to travel had he the offer accepted

b. Er hat das Angebot angenommen, nach Afrika $\mathrm{zu}$ reisen. he had the offer accepted to Africa to travel 'He accepted the offer to travel to Africa.' non-finite clause

(31) a. Ob wir so verfahren sollten, stellte sie die Frage. if we so proceed should posed she the question

b. Sie stellte die Frage, ob wir so verfahren sollten. she posed the question if we so proceed should 'She posed the question if we should proceed this way.' interrogative

All these cases involve displaced sentential complements to nouns. A note of caution is in order. The terms sentential complements to nouns or NCC should, for lack of a better understanding, be understood in a functional sense. That is, the term is not necessarily supposed to mean that these CPs are complements to nouns in terms of $\bar{X}$-theory or its successors. While in all the cases, the NCC functions as an argument to the noun, this should not be equated with the claim that NCCs are structural complements (i.e. sisters) to the noun. There are reasons to believe that they are not; rather, they appear to behave like adjuncts. For example, they can swap positions with relative clauses, given some tweaking of intonation (32). ${ }^{9}$

\footnotetext{
${ }^{9}$ This line of argumentation takes a rather simple-minded view of nominal argument structure and disregards the possibility that there are "nominal shells" along the lines of Larson and Yamakido (2008), where NCCs could readily be complements of (the base positions of) nouns. Alternatively, one could entertain the idea that these sentential arguments to nouns are base-
} 
(32) a. ?Sie hat diejenige Aussage, mit der niemand gerechnet hatte, she has the-one utterance with which no-one reckoned had dass die Proteste legitim sind, bekräftigt. that the protests legitimate are reinforced

b. Sie hat diejenige Aussage, dass die Proteste legitim sind, mit she has the-one utterance that the protests legitimate are with der niemand gerechnet hatte, bekräftigt.

which no-one reckoned had reinforced

'She confirmed the statement by the protester that the protests are legitimate, which no one had expected.'

Moreover, postnominal genitive DP attributes - arguably actual $\overline{\mathrm{X}}$-theoretic complements - can intervene between NCCs and the associated nouns, as in (33a); placement of the NCC between the head noun and the genitive DP is sharply out (33b).

(33) a. Sie hat die Aussage der Demonstrantin dass die Proteste she has the utterance the.GEN protester that the protests legitim sind bekräftigt. legitimate are reinforced

'She confirmed the statement by the protester that the protests are legitimate.'

b. *Sie hat die Aussage dass die Proteste legitim sind der she has the utterance that the protests legitimate are the.GEN Demonstrantin bekräftigt. protester reinforced

This constraint holds, irrespective of whether or not the NCC is finite (as in (33)) or non-finite (as in (34)).

a. Sie hat die Bekundung der $\begin{aligned} & \text { Demonstrantin } \\ & \text { protester }\end{aligned}$
she has the avowal
einzuhalten gutgeheißen.
in.to.hold approved
'She approved the avowal by the protester to observe the rules.'

The reason why the difference between finite and non-finite NCCs is relevant is because one could argue that (33) comes about by obligatory DP-internal extraposition of the finite $\mathrm{CP}$ as was observed at the clausal level ("heavy" material commonly ends up or has to end up in the Nachfeld - postfield - of the German clause). However, this reasoning is problematic in the face of (34): Extraposition of nonfinite subordinate clauses is optional in the clause domain, and therefore extraposition would implausibly have to be obligatory in the nominal domain.

generated in the complement position of the noun and then undergo (obligatory) rightward extraposition within the DP. 
More generally, postnominal genitive DPs exhibit what looks like an adjacency requirement with the head noun. For example, PP-arguments of nouns like an die Kunden ('to the costumer') cannot swap positions with genitive DPs, as shown by the contrast between (35a) and (35b).

(35) a. die Lieferung der Ware an die Kunden the delivery the.GEN goods to the costumers 'the delivery of goods to the costumers'

b. *die Lieferung an die Kunden der Ware the delivery to the costumers the.GEN goods

This adjacency requirement is likewise at work in (33b). ${ }^{10}$ Concluding, the evidence suggests a structure like (36a) for NCCs, rather than (36b).

(36) a. $\left[N^{\prime} \mathrm{N}^{\prime} \mathrm{CP}\right]$

b. $\left[N^{\prime} \mathrm{N} \mathrm{CP}\right]$

Nevertheless, I retain the term NCC for expository purposes and ask the reader to keep this in mind. In section 3.3, I will go into the issue of the impossibility of extracting other sentential adjuncts to DPs, namely relative clauses. Upon that, I will return to syntactic characteristics of NCC-extraction.

\subsection{Restrictions on sentential extraction from DPs}

As the name NCC suggests, the phenomenon exhibits restrictions with respect to the type of noun-associated clause that can be involved. Particularly, only clauses functioning as complements to nouns can figure in the construction, and not, say, a clause modifying the noun, like a relative clause. ${ }^{11}$

*Die wir gut nachvollziehen konnten, hatte sie eine Auffassung
which we well understand
vertreten.
represented
Intended: 'She had defended a view which we could well understand.'

${ }^{10}$ This adjacency requirement holds irrespective of the thematic role borne by the genitive DP. Thus, for example, agentive genitive DPs must be adjacent to the head noun, and patientPPs cannot intervene.
(i) a. die Aufforderung der Lehrerin an die Schüler the request the.GEN teacher to the pupils 'the request by the teacher to the students'
b. *die Aufforderung an die Schüler der Lehrerin the request to the pupils the.GEN teacher

${ }^{11}$ There are reasons to believe that other types of noun-modifying adverbial clauses are essentially relative clauses, syntactically, with special semantic restrictions on the head noun; see, for example, Lasersohn (1996) and Frana (2017) for approaches to the semantics of English adnominal conditionals, and Blümel (2019) for an analysis of the German counterpart and considerations on their syntax. 
The deviance of this sentence is clear-cut. Arguably, this can be attributed to an independently operative ban on a surface order in which the relative clause precedes the associated head noun.

(38) Relative clauses must be linearly preceded by an overt instance of their associated head noun.

Indirect evidence for this restriction being in effect comes from fronting of remnant VPs to which a relative clause is adjoined. Full VP-fronting as in (39a) shows that right-adjunction of a relative clause is possible, provided the head-DP linearly precedes the relative clause in fulfilment of (38). Example (39b) is an instance of remnant VP-fronting, again with a relative clause-CP adjoined to the remnant VP, as the schematic analysis in (40) illustrates. Crucially, (39b) violates (38).

(39) a. Das Buch lesen, das ihr gerade geschenkt worden war, wollte the book read which her just given became was wanted Maria sofort.

M. immediately

'As for reading the book, which she had just been given, Mary wanted to do that right away.'

b. *Lesen, das ihr gerade geschenkt worden war, wollte Maria das read which she just given became was wanted $M$. the

Buch sofort. book immediately

(40) $\left[_{V P}\left[{ }_{V P}<\right.\right.$ das Buch $>\mathrm{V}=$ lesen $\left.] \mathrm{CP}\right]$...das Buch

If (38) is the cause for the deviance of (39b), the condition might likewise be the reason for the ill-formedness of (37). This line of reasoning gives rise to an interesting expectation: (38) is silent on the possibility that NCCs linearly precede their associated head nouns. This captures the observed phenomenon under investigation in this article. However, it is possible to go beyond stating the observed facts and form the NCC-analogue of (39b). The expectation then is that it is at least better than their relative clause counterparts. This expectation is only partially met; remnant VP-fronting with a right-adjoined NCC is distinctively more acceptable than its relative clause kins.

(41) a. ?Geäussert, dass wir so verfahren sollten, hat sie die Meinung uttered that we so proceed should has she the opinion durchaus.

indeed

'She uttered the opinion that we should proceed this way.'

The improvement the example (41) represents could be due to a parsing error: Possibly, the matrix verb and the immediately following subordinate dassclause are initially parsed as a predicate argument structure. Only upon hitting the DP die Meinung does this parse have to be corrected. But since the spurious clausal argument explicates the DP, the structure is intelligible, albeit arguably ungrammatical. 
This line of reasoning is confirmed by the fact that once a verb is used that does not form Funktionsverbgefüge (light verb constructions) with the selected DP, acceptability decreases sharply.

(42) a. *Bewundert, den Mt. Blanc zu besteigen, hat Maria den Versuch dann admired the Mt. B;anc to climb has Maria the attempt then allerdings schon. on-the-other-hand PTCL

Intended: 'On the other hand, Mary admired the attempt to climb the Mt. Blanc.'

b. *Gestellt, ob wir so verfahren sollten, hat sie die Frage. put if we so proceed should has she the question Intended: 'She posed the question if we should proceed this way.'

The deviance of the examples (42) arguably has to do with two factors: Firstly, no parallel parsing and structural assignment along the lines suggested for (41) is possible, because the subordinate clauses cannot be taken to be arguments to the verbs bewundert 'admired' and gestellt 'pose' respectively. Thus, no illusion arises that the subordinate clause is such an argument. Secondly, the said verbs and the DPs den Versuch and die Frage do not relate closely, semantically, that is, they do not form a Funktionsverbgefüge. This is unlike the DP die Meinung and the verb geäussert in (44), which can essentially be paraphrased as 'Indeed she was of the opinion that we should proceed this way.'

What cannot be concluded from this discussion is that (38) affects NCC-remnants as well: Firstly, (41) plainly evades (38). Secondly, all other acceptable cases of NCC-fronting evade (38). More needs to be said on the matter, but it should be clear that the possibility of forming Funktionsverbgefüge is one crucial factor in fronting NCCs, and likewise in applying remnant-VP-fronting with extraposed NCC. Example (42b) makes this particularly clear in that the embedded interrogative cannot function as the complement of the verb stellen 'put' (the cause for the deviance) while the meaning of the predicate ('to ask'/"pose the question') is recoverable only at the point when the object DP die Frage gets parsed. The unacceptability of (42) can be traced to semantic or functional issues: sentential adjuncts which are explicative CPs may be extracted, while non-explicative CPs may not be extracted.

\section{SOME SYNTACTIC CHARACTERISTICS}

In this section I examine some syntactic characteristics of displaced NCCs with the aim of pinpointing the type of dependency between the NCC and the DP-internal gap.

\section{1 $\bar{A}$-movement}

This section seeks to establish that the dependency between the sentence-initial NCC and the (presumed) postnominal gap involves actual syntactic movement of the CP, and more particularly, $\bar{A}$-extraction. That is, I argue that (43) derives from an independently available structure, along the lines of (44). 
(43) Dass wir so verfahren sollten, war sie [der Ansicht $e$ ]. that we so proceed should was she the opinion 'She was of the opinion that we should proceed this way.'

(44)

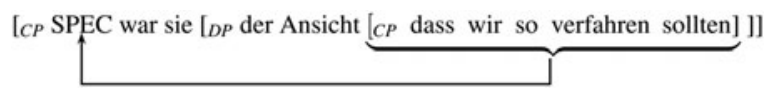

To do this, I apply a number of standard tests for $\overline{\mathrm{A}}$-movement, which will inform the analytical possibilities.

In variants of German that allow long distance movement, NCC-extraction can apply over boundaries of finite clauses.

(45) Dass wir so verfahren sollten, hat Peter gemeint, dass sie [der Ansicht $e$ ] that we so proceed should has Peter meant that she the opinion war.

was

'Peter said that she was of the opinion that we should proceed this way.'

This may serve as a first indication that movement is involved. NCC-extraction is, furthermore, sensitive to several kinds of islands, lending further support for the conclusion. One such island is a complex DP. Example (46) shows that NCC-extraction may not apply to a DP inside another complex (here: relativized) DP. The result is sharply unacceptable.

(46) *Dass wir so verfahren sollten, hat Peter [das Mädchen das der Ansicht $e$ the we so proceed should has Peter the girl who the opinion war] getroffen. was met

Furthermore, to the extent that extraction out of a weak island is impossible, it is not possible to NCC-extract from an embedded polar question, as (47) shows.

(47) *?Dass wir so verfahren sollten, hat Peter sich gefragt, [ob Fritz der that we so proceed should has Peter REFL asked if Fritz the Ansicht $e$ war].

opinion was

Finally, the subject condition restrains NCC-extraction, as (48) illustrates, again parallel to what was found with PP-extraction from DPs; see (49a)/(49b). ${ }^{12}$

${ }^{12} \mathrm{~A}$ caveat is in order: The status and validity of the constraint in German is notoriously unclear, but see Jurka et al. (2011) for an experimental approach based primarily on was-für split.

Haider (2010: 41) gives an impeccable case (i) (which violates the Specificity Condition at that).

(i) [Von welchem Künstler] haben [die frühen Werke $e$ ] die besten Preise erzielt? of which artist have the early works the best prices gained

'The early works of which artist have gained the best prices?'

More research is required, investigating and controlling lexical choices of $\mathrm{V}$ and $\mathrm{N}$ as well as prepositions (here: a von-PP), the complement-adjunct distinction, the bridging usage (see Clark 1975, Prince 1981) that appears to play a role in (i), as well as other factors, in order to clarify these complications and uncertainties. 
(48)

$\begin{array}{ccccc}\text { *?Dass wir so verfahren } & \text { sollten, } & \text { hat }[\text { die Auffassung } e] & \text { niemanden } \\ \text { that we so proceed } & \text { should } & \text { has the opinion } & \text { no-one }\end{array}$
überzeugt. convinced
a. *Zum ECP hat eine Frage den Professor verärgert. on-the ECP has a question the professor annoyed Intended: 'A question about the ECP annoyed the professor.'

Grewendorf (1989: 36)

b. *Zur Polenfrage
$\begin{aligned} & \text { hat eine } \\ & \text { on-the Poland-question } \\ & \text { geklärt. }\end{aligned}$
cleared

Intended: 'An assembly on the question regarding Poland solved some issues.'

Fanselow (1987: 76)

In this context, it should be noted that passivization ameliorates the violation of the subject condition; see (50).

(50) ?Dass wir so verfahren sollten, wurde [die Hoffnung e] geäussert. that we so proceed should was the hope uttered

'The hope was expressed that we would proceed this way.'

This is expected if, in passives, the grammatical subject is an underlying object. And again, such observations are familiar from corresponding effects with PP-extraction from DPs (see, e.g., Chomsky 2008: 147/153 on wH-extraction from derived subjects).

Does NCC-extraction have to target the "prefield" of the clause? Extraction of finite NCCs (51) must not target the "middle field", ${ }^{13}$ suggesting that this is so.

(51) *?War sie dass wir so verfahren sollten [der Ansicht $e]$ ? was she that we so proceed should the opinion

Intended: 'Was she of the opinion that we should proceed this way?'

That is, one could argue that there is no NCC-scrambling. However, notice that scrambling of a non-finite NCC leads to a distinct improvement, (52).

(52) ?Hat sie so verfahren $\mathrm{zu}$ können wirklich [die Hoffnung $e$ ] geäussert? has she so proceed to can really the hope uttered

Intended: 'Did she really express the hope that we could proceed this way?'

Plausibly, then, the contrast between (51) and (52) can be traced to the independently operative ban on finite subordinate CPs in the middle field. If so, and if NCCextraction patterns like regular $\overline{\mathrm{A}}$-movement, one can reason as follows: V2-clauses are known to be distinctively worse in the middle field than, for instance, finite verb-

\footnotetext{
${ }^{13}$ The term "middle field" denotes the area of the German clause between left sentence bracket and the right sentence bracket. $\bar{X}$-theoretically, they are commonly treated as the Chead and the head-final VP (in addition to a head-final TP, maybe) such that the middle field are the SPEC-VP-position and the verb's complement position, plus adverbial modifiers. Scrambling takes place within the middle field.
} 
final clausal complements. It is then expected that scrambling of NCCs is limited to the extent that clausal complements can appear at all in the middle field and that scrambling of a V2-NCC is the least acceptable among the clause types. The expectation is met as (53) shows.

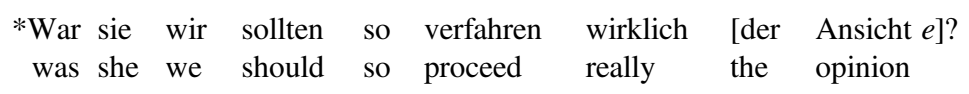

Notice that the possibility of scrambling non-finite NCCs, as shown in (52), appears to be a problem for an analysis of the NCC that involves base-generation of NCC in the left periphery in addition to a silent operator undergoing $\bar{A}$-movement from within the DP. Essentially, NCCs are not confined to the clausal left periphery, just as PPs extracted from DPs are not, as (54) shows.

(54) dass darüber wohl niemand ein Buch gelesen hat that there-over PTCL no one a book read has 'that no one read a book about that'

To conclude this section, based on several established diagnostics, I have argued that NCC-extraction is an instance of $\bar{A}$-movement. I will now move on to the issue of the choice of verbs selecting the DP containing the gap.

\subsection{Verb classes}

PP-extraction from DPs exhibits a sensitivity to the selecting verb as examples (5)/ (7)/(23) show. NCC-extraction from DPs features a comparable sensitivity. Acceptable cases include (55a)-(56a) with the verb-DP combinations die Frage stellen ('pose the question') and den Versuch unternehmen ('make the attempt'). These contrast with instances of NCC-extraction with negative verbs like zurückweisen 'reject' (lit. back-show), (55b), and abbrechen 'cancel', (56b), which are ungrammatical.

(55) a. Ob wir so verfahren sollten, stellte sie die Frage. if we so proceed should posed she the question 'She asked if we should proceed this way.'

b. *Ob wir so verfahren sollten, wies sie die Frage zurück. if we so proceed should showed she the question back Intended: 'She rejected the question if we should proceed this way.'

(56) a. Den Mt. Blanc zu besteigen hatten sie den Versuch unternommen. the Mt. Blanc to climb had they the attempt undertaken 'They made the attempt to climb the Mt. Blanc.'

b. *Den Mt. Blanc zu besteigen hatten sie den Versuch abgebrochen. the Mt. Blanc to climb had they the attempt cancelled Intended: 'They cancelled the attempt to climb the Mt. Blanc.'

As before, this parallels instances of PP-extraction from DPs. It is no surprise that Funktionsverbgefüge enhance the acceptability of the NCC-extraction examples. Such constructions feature a semantically "light" or bleached verb or an auxiliary verb, in addition to a semantically more content-full noun. For example, den 
Versuch unternehmen (the attempt undertake, 'to attempt') conveys effectively the meaning of the verb translation. The reason for the enhanced acceptability of NCC-extraction thus appears to be that acceptable DP-V-sequences allow for the paraphrasing with a single verb.

(57) a. Dass wir so verfahren, dachte/meinte sie (=war sie der Ansicht). that we so proceed thought/meant she (=was she the opinion)

b. Dass die Leute noch erscheinen würden, hoffte sie (=hatte sie die Hoffnung). that the people still appear would hoped she (=had she the hope)

c. Ob wir so verfahren sollten, fragte sie (=stellte sie die Frage) if we so proceed should asked she (=posed she the question)

d. Den Mt. Blanc zu besteigen, hatten sie versucht the Mt. Blanc to climb had they attempted (=unternahmen sie den Versuch) (=undertook they the attempt)

Essentially then, the types of semantic relationships N-V-sequences can entertain facilitate or inhibit extraction from DPs quite generally, and NCC-extraction is no exception. A thorough investigation into the types of relationships between the verbs and the nouns is an important research task, but beyond the scope of this article.

\section{3 (In)definiteness/(Un)specificity}

The Specificity Condition is violated in all examples hitherto considered. That is, NCCextraction from definite DPs is permitted, and indeed, required. In this respect, NCCextraction contrasts with PP-extraction, of which (58) is a German example.

$$
\begin{array}{llllll}
* \text { Worüber } & \text { hat } & \text { Fritz } & \text { das/dieses/Chomskys } & \text { Buch } & \text { gelesen? } \\
\text { where-over has } & \text { Fritz the/this/Chomsky's } & \text { book } & \text { read }
\end{array}
$$

The fact that all NCC-extraction cases violate the Specificity Condition as such raises questions. At the same time, it is unsurprising, given the co-occurrence pattern with different determiner types of NCCs contiguous with their associated nouns: They all require definite determiners. ${ }^{14}$

(59) a. Sie war der Ansicht, dass wir so verfahren sollten. she was the opinion that we so proceed should

b. $\{\# / *\}$ Sie war einer Ansicht, dass wir so verfahren sollten. / $\{\# / *\}$ Sie she was an opinion that we so proceed should she stellte eine Frage, ob wir so verfahren sollten. posed a question if we so proceed should

While general conditions of possible specificity violations remain to be understood, the violation in NCC-extraction appears to follow the rule saying NCCs generally require a definite DP. I will move on to possessed DPs. The introduction

\footnotetext{
${ }^{14}$ See Bech's (1983) idea that NCC explicate the definite determiner in Fabricius-Hansen and von Stechow 1989: 197.
} 
of prenominal possessors within the complex DP leads to a degradation of NCCextraction.

(60) a. Maria bewunderte [Edes Versuch, [den Mt. Blanc zu besteigen]]. Maria admired Ede's attempt the Mt. Blanc to climb 'Mary admired Ede's attempt to climb the Mt. Blanc.'

b. ?*[Den Mt. Blanc zu besteigen] bewunderte Maria [Edes Versuch]. the Mt. Blanc to climb admired Maria Ede's attempt

The deviance represented by (60b) is puzzling, given the acceptability of (60a). I have no solution to offer.

Returning to the Specificity Conditions with definite articles, notice that violations, even with PP-extraction, are not unheard of, see (61a) and (61b) (from Davies and Dubinsky 2003: 18, Huang 1982 (cited in Chomsky 1986: 80)).

(61) a. What did they observe the production of?

b. Which city did you witness the destruction of?

According to Davies and Dubinsky (2003), the choice of noun is crucial in lifting the Specificity Condition: Extraction out of definite DPs headed by process nouns like production or destruction is fine, as opposed to such with concrete or result nouns.

Davies and Dubinsky (2003: fn. 7) consider the possibility that definites function differently in process nominals than with result nouns in a number of other respects as well. First, the definite determiner is often optional, as in (62).

(62) Scientists observed revolution of a satellite around Mars.

Secondly, process nouns introduced by the definite article often do not require presupposed existence, as in (63), that is, the familiar semantic property often subsumed under existential presupposition is not adhered to with process nouns.

(63) To account for the observed solar wobbles, some scientists have posited (the) revolution of the sun around some unknown gravity source.

Finally, definite subject-DPs with process nouns may occur in existential constructions, which usually dislike definite DPs, as shown in (64).

(64) And then, there was the revolution of a satellite around Mars on the video transmission, which the scientists had not expected.

These observations indicate that the definite article plays a different role in process nouns. Possibly, process nouns might give rise to an expletive article reading, in the spirit of Longobardi (1994).

Can these tests be replicated with nouns which take NCC-complements? Caution is required before making such transfers, because (a) we are dealing with a different semantic category of noun and (b) German definite articles behave somewhat differently from English ones. Certainly, omission of the article (in singular nouns) in NCC-contexts yields degradation, as in (65).

$\begin{array}{llll}\text { * Sie hat } & \text { [Behauptung dass } & \text { er inkompetent } & \text { sei] } \\ \text { she has claim } & \text { that } & \text { he incompetent } & \text { be made }\end{array}$


Regarding existential constructions, one can observe that NCC-DPs can figure in them, while other definite DPs cannot (compare (66) with (67a) and the latter with (67b)). ${ }^{15}$

(66) Und dann gab es [die Behauptung dass er inkompetent sei], womit niemand and then give it the claim that he incompetent be where with no one gerechnet hatte.

reckoned has

'And then there was the claim that he was incompetent, which no one had expected.'

(67) a. *?Gestern gab es [den Jungen] in der Mensa, womit niemand yesterday give it the boy in the cafeteria where with no one gerechnet hatte.

reckoned has

b. Gestern gab es [einen Jungen] in der Mensa, womit niemand yesterday give it a boy in the cafeteria where with no one gerechnet hatte. reckoned has

'Yesterday, there was a boy in the canteen, which no one had expected.'

So NCC-DPs in German do exhibit certain parallels to English process nouns, but these are not consistent but confined to existential contexts. The definite article is clearly not optional for NCC-DPs, unlike what was observed for process nouns in English.

Considering determiners other than articles, NCC-extraction is licit if the associated DP is introduced by a quantifier (68).

(68) Dass er das Handout noch schaffen würde, hatte er alle/?jede Hoffnung that he the handout still finish would had he all/every hope schon aufgegeben. already up-given

'He had already given up all hope that he would still finish the handout on time.'

And again, this is quite expected, given that these quantifiers can figure in NCCcontext when no extraction takes place. The emerging generalization is that NCC-extraction is not subject to the Specificity Condition. Instead, it seems as if NCC-extraction is possible with DPs that can also figure in non-extraction NCC-contexts. The observations complicate the already intricate picture of extraction from DP-phenomena. However, within the confines of NCC they appear to be quite

\footnotetext{
${ }^{15}$ Using the "prefield"-es ('it') as a pronominal expletive in SPEC-CP is misleading, in my view, as it appears to do little more than structurally fulfill the V2-requirement. While doing so does deliver an existential sentence, direct comparison with English strikes me as somewhat difficult.

Instead, I choose a verb of existence geben (lit. 'give', actually: 'there is') which lexically comes with the homophonous expletive. This expletive can show up in the middle field of the German clause and thus establishes conditions that mirror the corresponding ones in English more closely. In V2-contexts, the distinction between the two types of expletives can get blurred, but agreement with the verb or the lack thereof reveals the type of expletive: The pure prefield-es does not control agreement, unlike the ones that lexically accompany certain verbs (verbs of existence, atmospheric predicates/weather verbs, etc.).
} 
consistent and expected, given the in-situ counterparts. Let me next move on to reconstruction effects.

\subsection{Reconstruction effects}

Connectivity effects commonly serve as a diagnostics for movement, that is, they indicate the base-generated position of a phrase; the absence of connectivity effects can be taken as an indication of the absence of movement. Reconstruction effects are instances of such connectivity effects. The well-established contrast between Left Dislocation (69a) and Hanging Topic Left Dislocation (69b) in German may serve as an example (taken from Grohmann 2000: 75-76).
a. Diesen Satz, den mag ich besonders. this.ACC sentence, that.ACC like I especially 'This sentence, I like (it) especially.'
b. Dieser Satz, den mag ich besonders. this.NOM sentence, that.ACC like I especially 'This sentence, I like it especially.'

Both constructions involve a left-peripheral XP, the DPs diesen Satz or dieser Satz respectively. This XP is resumed by a demonstrative pronoun, den ('that') in (69a)/(69b). The displaced DP matches in case with the demonstrative in Left Dislocation, while in Hanging Topic Left Dislocation, the DP in the left-peripheral position invariably bears nominative. Case betrays the DPs clause-internal base-position in Left Dislocation, because the verb mögen ('like') governs accusative. This is a connectivity effect. No such effect is observable in Hanging Topic Left Dislocation. Semantic effects (not shown here) like reconstruction for Binding theoretic Principles (Chomsky 1981) and for variable binding further corroborate the conclusion, namely that in Left Dislocation, the XP is syntactically associated with a clause-internal gap. In Hanging Topic Left Dislocation, no such reconstruction is observed, which commonly is taken to indicate the absence of a movement dependency between the XP and a clause-internal position.

I take these diagnostics as given and apply them to NCC-extraction. If NCCextraction exhibits reconstruction effects, the conclusion receives support that the left-peripheral NCC is associated with the postnominal position by a movement dependency. These diagnostics do not conclusively show that movement is involved; however, it needs to be shown how they can be made to follow from an analysis involving base generation of the NCC in the left-peripheral position.

As it turns out, there are effects of reconstruction for Principle $\mathrm{C}$ of the Binding Theory, as (70a) shows; ${ }^{16}$ (70b) is the corresponding in-situ case. In both cases, the pronominal and the R-expression Peter cannot receive a co-construal reading.

\footnotetext{
${ }^{16}$ Speakers were not unanimous in evaluating reconstruction for Principle C. For some speakers it was obligatory; for other it was impossible. For those speakers who held that reconstruction is not obligatory, comparable observations on the reconstruction of antecedent clauses in conditionals apply that Bhatt and Pancheva (2006) brought to the fore: reconstruction is an option, not a requirement.
} 
(70) a. *Dass Peter ${ }_{i}$ so verfahren sollte, äusserte $\mathrm{er}_{i}$ die Meinung. that $P$. so proceed should uttered he the opinion

b. $* \mathrm{Er}_{i}$ äusserte die Meinung, dass $\mathrm{Peter}_{i}$ so verfahren sollte. he uttered the opinion that $P$. so proceed should * ' $\mathrm{He}_{i}$ was of the opinion that Peter $_{i}$ should proceed this way.'

If the left-peripheral $\mathrm{CP}$ in (70a) is base-generated in its surface position or a hanging topic, respectively, these cases are difficult to explain.

Instances of reconstruction for quantificational binding support a similar conclusion. The example (71a) allows for a construal in which the pronoun embedded in the left peripheral clause covaries with the universal quantifier in the main clause.

(71) a. Dass er ${ }_{i}$ so verfahren sollte, war jeder ${ }_{i}$ der Ansicht. that he so proceed should was everyone the opinion

b. Jeder $_{i}$ war der Ansicht, dass $\mathrm{er}_{i}$ so verfahren sollte. everyone was the opinion that he so proceed should 'Everyone ${ }_{i}$ was of the opinion that he ${ }_{i}$ should proceed this way.'

Reconstruction for Principle $\mathrm{C}$ and facts from variable binding suggest that dislocated NCCs involve syntactic movement.

Scrambling of NCCs will be considered next. There is a distinct effect for reconstruction of Principle C in contexts where the NCC is scrambled; see (72a), where the in-situ counterpart is given as (72b) for comparison.

(72) a. *Dass [Peter ${ }_{i}$ fein anzuziehen] $\mathrm{er}_{i}$ [die Absicht] gehabt hatte, war that $\mathrm{P}$ finely to-dress he the intention had had was niemandem aufgefallen.

no one noticed

b. *Dass er $_{i}$ [die Absicht [Peter ${ }_{i}$ fein anzuziehen]] gehabt hatte, war that he the intention P finely to-dress had had was niemandem aufgefallen.

no one noticed

*'No one had noticed that he ${ }_{i}$ had had the intention to dress Peter $_{i}$ nicely.'

To repeat, this suggests that the scrambled NCC is not base-generated in its surface position, because under base-generation the Condition $\mathrm{C}$-effect is puzzling: No c-command would hold between er and Peter at any point in the derivation. Moreover, it shows that scrambled NCCs are not subject to anti-reconstruction effects, their presumed syntactic status of an adjunct notwithstanding.

Comparing reconstruction of Principle $\mathrm{C}$ with the state of affairs of reconstructing for bound variable readings corroborates the previous observation. As (73b) shows, reconstruction of a scrambled NCC for a bound variable construal is a possibility.

(73) a. Dass [seine ${ }_{i}$ Schwester mitzunehmen] jeder ${ }_{i}$ [die Absicht] hatte, that his sister with to take everyone the intention had war klar. was clear 
b. Dass jeder ${ }_{i}$ [die Absicht [seine ${ }_{i}$ Schwester mitzunehmen]] hatte, that everyone the intention his sister with to take had war klar. was clear 'It was clear that everyone ${ }_{i}$ had the intention to bring along his ${ }_{i}$ sister.' $^{2}$

Again, these observations support the previous conclusion that NCCs reconstruct in a DP-internal position.

As a final reconstruction diagnostic, Negative Polarity Items (NPI) can show up in displaced NCCs, with a negative element structurally intervening between the NCC's surface position and the DP-internal gap. I use the NPI jemals ('ever').

(74) a. ?Dass Fritz jemals wiederkommen würde, hat niemand die that Fritz ever back come would has no-one the Auffassung vertreten. opinion represented

b. Niemand hat die Auffassung vertreten, dass Fritz jemals no-one has the opinion represented that Fritz ever wiederkommen würde. back come would 'No-one was of the opinion that Fritz would ever return again.'

If the NCC is base-generated within the DP, the negative subject c-commands and licenses the NPI. If the NCC is base-generated in the left-periphery, (74a) should be bad.

To conclude, facts from reconstruction for Principle $\mathrm{C}$, variable binding and NPI-licensing are not expected if the NCC is base-generated in its surface position, while they fall in place if movement is posited to characterize the dependency between the NCC and the DP-internal gap.

\subsection{A tentative conclusion}

I take both the possibility of scrambling and the reconstruction effects to tentatively indicate that the NCC-extraction does involve movement of the actual clause from a DP-internal position. That is, for now I disregard the possibility that the left-peripheral clauses are, for example, hanging topics, maybe associated with a silent operator in SPEC-CP of the host-clause. I would like to emphasize and repeat, though, that the conclusion is tentative, because it hinges on the delicate judgments involved in the construction more generally.

\section{FURTHER CONSIDERATIONS ON AN ANALYSIS}

In this section I would like to address further aspects that any analysis of NCC-extraction needs to take into consideration. These pertain to the types of nouns.

\subsection{Explicative vs. implicative complement to nouns}

Based on a number of criteria, Fabricius-Hansen and von Stechow (1989) establish a distinction between two types of NCCs, which they name implicative (75a) and explicative (75b) nominal complementation respectively. 


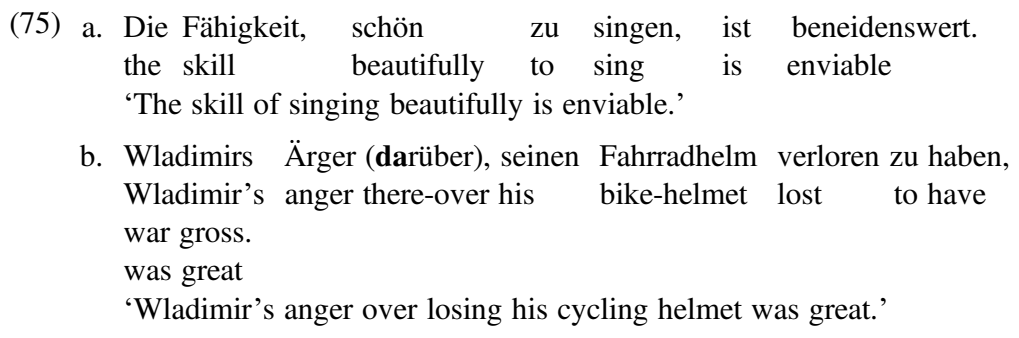

Explicit NCCs are characterized by their possibility of coming with a pronominal element which functions as a correlate to the NCC. Example (75b) shows this with the possibility of a postnominal PP, which has an R-pronominal correlate in it. ${ }^{17}$ Implicit NCCs, by contrast, do not straightforwardly have this option. Another important difference between the two is the following: The head noun can function as a predicate in explicative NCCs (76a), while this is impossible in implicative NCCs (76b) (Fabricius-Hansen and von Stechow 1989: 175).
(76) a. Schön zu singen ist eine Fähigkeit, die nicht jeder hat. beautifully to sing is a skill which not everybody has 'Not everyone has the skill to sing beautifully.'
b. *Seinen Fahrradhelm verloren zu haben ist ein Ärger, der gross his cycling helmet lost to have is an anger which great war. was Intended: 'The anger over losing his cycling helmet was great.'

Is there a correlation between the distinction between implicative and explicative NCCs and the possibility of extracting the sentential complement? Sticking to the relevant examples, there is no discernible difference.
a. *Schön zu singen hat sie die Fähigkeit. beautifully to sing has she the skill Intended: 'She has the skill to sing beautifully.'
b. *Seinen Fahrradhelm verloren $\mathrm{zu}$ haben hatte er den Ärger. his cycling helmet lost to have had he the anger Intended: 'He had the trouble of having lost his cycling helmet.'

These observations do not allow for strong conclusions, but deserve further investigation. $^{18}$

\footnotetext{
${ }^{17}$ Strictly speaking, NCC is a misnomer here, because a PP embeds the clause.

${ }^{18}$ Let me make a brief remark on the semantic character of the examples. All examples considered are best when the verb within the NCC is in subjunctive mood or involves a modal verb. This strongly suggests a possible world semantics of the NCC. Quite fitting is the observation that many nouns involve a modal component (Möglichkeit 'possibility', Wahrscheinlichkeit 'probability', Aussicht 'prospect', etc.). All of these observations strongly suggest that the semantics of the construction be captured by a restrictor analysis of the NCCs, maybe along the lines of Moulton (2009). Therein, a modal operator forms a relation between two sets of possible worlds - the meaning of the intensional noun itself, and the one of the
} 


\subsection{A remark on an analysis}

This section touches on aspects that an analysis of NCC-extraction from DPs should take into consideration. That is, in lieu of an analysis it offers hints at an analysis. Pending a better understanding of the factors involved, I believe that a full-fledged formal analysis is premature. Yet, I would like to pursue an intuition that might hint at something like the common denominator of the phenomena described in this article, or at least capture a property most of the phenomena have in common.

There is a recurring theme when it comes to analyzing extraction from DP. The general idea is that the islandhood of a constituent can be lifted when a bound pronominal occupies a left peripheral position of the island. Ingredients of the approach by Davies and Dubinsky (2003: 32) are given in (78).

(78) NCC hatte sie ${ }_{1}\left[D P\right.$ die $\left[F P \mathrm{PRO}_{1} \mathrm{~F}\left[N P\right.\right.$ Hoffnung $\left.\left.\left.t_{N C C}\right]\right]\right]$
NCC had she the
gope

The subject of the verb controls the attitude or mental state of the subject of the embedded (noun-containing) clause (result nouns for Davies and Dubinsky 2003: 32, but deverbal nominals for the cases at hand): One way of encoding this is to use PRO. PRO would then occupy the specifier position of an FP, which is sandwiched between DP and NP. Moreover, PRO would be bound by the clausal subject. Next, one could state that extraction from DP is licit iff PRO is locally bound.

Similar island-ameliorating effects of bound pronouns in island-edge positions have recently been reported by Grano and Lasnik (2018) (see Huang 2018 on DPs). Grano and Lasnik's (2018) assumptions include the following:

- Bound pronouns optionally enter the derivation with unvalued $\phi$-features.

- Phases are in part defined by convergence, so that unvalued features may void a phase and in effect extend the locality domain of syntactic operations.

There is an undesirable empirical prediction that follows from the analysis if one adopts Grano and Lasnik's (2018) approach to account for NCC-extraction from DPs. Remember that passives improve NCC-extraction and arguably also unaccusatives. However, these do not obviously involve external arguments which can function as binders. For the analysis to work, one would have to assume that PRO must be bound by a structurally represented silent by-phrase or some counterpart in unaccusatives. While this might work technically, it neither promises to shed light on the reasons why extraction is possible in some cases but not in others, nor is such an approach plausible.

\section{Conclusion}

The present article has given a first descriptive stab at the possibility of noun complement clause extraction from DPs in German. Several tests were applied to the construction to establish that movement is involved. Moreover, one can conclude that adjunct extraction is not generally disallowed, but permitted if the adjunct has the

NCC. Let me add that certain types of nouns like Ansicht 'view', Auffassung 'opinion', Glaube 'faith' (see Bierwisch 1989: 50-51) might fall into a similar rubric. 
function of an argument to the noun. The Specificity Condition on extraction from DPs generally fails to hold in noun complement clause extraction from DPs in German. It was confirmed that the verb and the noun must form a 'natural predicate' for extraction to be licit.

Further studies should address (a) the relationship between the embedding verb and the noun, and (b) the reason why specificity is sometimes not a factor preempting extraction, which plausibly has to do with the choice of nouns involved. Such investigations must be left for future work.

\section{REFERENCES}

Abney, Steven. 1987. The English noun phrase in its sentential aspect. Doctoral dissertation, MIT.

Bach, Emmon, and George Horn. 1976. Remarks on 'Conditions on Transformations'. Linguistic Inquiry 7(2): 265-299.

Baker, Mark. 1988. Incorporation: A theory of grammatical function changing. Chicago: University of Chicago Press.

Bech, Gunnar. 1983. Studien über das deutsche Verbum infinitum [Studies on the German infinitive verb], Band I (= Det Kongelige Danske Videnskabernas Selskab, Historisk-filologiske Meddelser), vol. 35. København. Nachdruck: Niemeyer, Tübingen 1955.

Bhatt, Rajesh, and Roumyana Pancheva. 2006. Conditionals. In The Blackwell Companion to Syntax, ed. Martin Everaert and Henk van Riemsdijk, vol. 1, 638-687. Oxford: Blackwell.

Bierwisch, Manfred. 1989. Event Nominalization: Proposals and problems. In Wortstruktur und Satzstruktur [Word structure and sentence structure], ed. W. Motsch, Linguistische Studien [Linguistic Studies], vol. 194, 1-73.

Blümel, Andreas. 2019. Adnominal conditionals in German. Linguistics Vanguard 5(3): 1-9. Bruening, Benjamin. 2009. Selectional asymmetries between CP and DP suggest that the DP Hypothesis is wrong. In U. Penn Working Papers in Linguistics 15.1: Proceedings of the $32^{\text {nd }}$ Annual Penn Linguistics Colloquium, ed. Laurel MacKenzie, 26-35.

Bruening, Benjamin, Xuyen Dinh, and Lan Kim. 2018. Selection, idioms, and the structure of nominal phrases with and without classifiers. Glossa 3(1): 1-46.

Cattell, Ray. 1976. Constraints on Movement Rules. Language 52(1): 18-50.

Chomsky, Noam. 1973. Conditions on Transfomations. In A Festschrift for Morris Halle, ed. Stephen R. Anderson and Paul Kiparsky, 232-286. New York: Holt, Rinehart and Winston.

Chomsky, Noam. 1977. On wh-movement. New York: Academic Press.

Chomsky, Noam. 1981. Lectures on government and binding: The Pisa lectures. Mouton de Gruyter.

Chomsky, Noam. 1986. Barriers. Cambridge, MA: MIT Press.

Chomsky, Noam. 2004. Beyond explanatory adequacy. In Structures and beyond, ed. Adriana Belletti, 104-131. Oxford: Oxford University Press.

Chomsky, Noam. 2007. Approaching UG from Below. In Interfaces + recursion = language?: Chomsky's minimalism and the view from syntax-semantics, ed. Uli Sauerland and HansMartin Gärtner. New York: Mouton de Gruyter.

Chomsky, Noam. 2008. On phases. In Foundational issues in linguistics, ed. Robert Freidin, Carlos Otero and Maria Luisa Zubizarreta, 133-166. Cambridge, Mass.: MIT Press. 
Clark, Herbert H. 1975. Bridging. In TINLAP '75 Proceedings of the 1975 Workshop on Theoretical Issues in Natural Language Processing, 169-174. Stroudsburg: Association for Computing Machinery.

Davies, William D., and Stanley Dubinsky. 2003. On Extraction from NPs. Natural Language and Linguistic Theory 21(1): 1-37.

De Kuthy, Kordula. 2001. Splitting PPs from NPs. In Constraint-based approaches to Germanic syntax, ed. Walt Detmar Meurers and Tibor Kiss, Studies in ConstraintBased Lexicalism 7, 31-76. Stanford, CA: CSLI Publications.

De Kuthy, Kordula. 2002. Discontinuous NPs in German - A case study of the interaction of syntax, semantics and pragmatics. Studies in Constraint-Based Lexicalism. Stanford, CA: CSLI Publications.

Fabricius-Hansen, Cathrine and Arnim von Stechow. 1989. Explikative und implikative Nominalerweiterungen im Deutschen [Explicative and implicative nominal complementation in German]. Zeitschrift für Sprachwissenschaft 8(2): 173-205.

Fanselow, Gisbert. 1987. Konfigurationalität - Untersuchungen zur Universalgrammatik am Beispiel des Deutschen [Configurationality - Investigations on Universal Grammar based on the example of German], Studien zur deutschen Grammatik [Studies on German grammar], vol. 29. Tübingen: Narr.

Fiengo, Robert, and James Higginbotham. 1981. Opacity in NP. Linguistic Analysis 7(4): 395-421.

Frana, Ilaria. 2017. Modality in the nominal domain: The case of adnominal conditionals. In Modality across syntactic categories, ed. Ana Arregui, María Luisa Rivero and Andrés Salanova, Oxford Studies in Theoretical Linguistics, vol. 63, 49-69. Oxford: Oxford University Press.

Gallego, Angel, and Juan Uriagereka. 2006. Conditions on Sub-extraction. In Proceedings of the Coloquio de Gramatica Generativa, vol. 16. Madrid: Universidad Autonoma de Madrid.

Georgi, Doreen, and G. Müller. 2010. Noun phrase structure by reprojection. Syntax 13.

Grano, Thomas and Howard Lasnik. 2018. How to neutralize a finite clause boundary: Phase theory and the grammar of bound pronoun. Linguistic Inquiry 49(3): 465-499.

Grewendorf, Günther. 1989. Ergativity in German. Dordrecht: Foris.

Grohmann, Kleanthes. 2000. Movement issues in left dislocation constructions. In Proceedings of the $24^{\text {th }}$ Annual Penn Linguistics Colloquium, vol. 7, 75-86.

Haider, Hubert. 2010. German syntax. Cambridge: Cambridge University Press.

Huang, James. 1982. Logical relations in Chinese and the theory of grammar. Doctoral dissertation, MIT.

Huang, Nick. 2018. The bound possessor effect: A new argument for the phasehood of definite DPs. In Proceedings of the $48^{\text {th }}$ annual meeting of the North East Linguistic Society, ed. Sherry Hucklebridge and Max Nelson, vol. 2, 39-52.

Jurka, Johannes, Chizuru Nakao, and Akira Omaki. 2011. It's not the end of the CED as we know it: Revisiting German and Japanese subject islands. In Proceedings of the $28^{\text {th }}$ West Coast Conference on Formal Linguistics, ed. Mary Byram Washburn, Katherine McKinney-Bock, Erika Varis, Ann Sawyer, and Barbara Tomaszewicz, 124-132. Somerville, MA: Cascadilla Proceedings.

Larson, Richard and Hiroko Yamakido. 2008. Ezafe and the deep position of nominal modifiers. In Adjectives and adverbs. Syntax, semantics, and discourse, ed. Louise McNally and Chris Kennedy, 43-70. Oxford: Oxford University Press.

Lasersohn, Peter. 1996. Adnominal conditionals. Semantics and Linguistic Theory 6: 154-166. 
Leu, Thomas. 2008. The internal syntax of determiners. Doctoral dissertation, New York University.

Leu, Thomas. 2015. The architecture of determiners. New York: Oxford University Press.

Lieb, Hans-Heinrich. 2005. Notions of paradigm in grammar. In Lexicology: An international handbook on the nature and structure of words and vocabularies, ed. Michael Job and D. Alan Cruse, Franz Hundsnurscher and Peter Lutzeier, vol. 2, 1613-1646. New York: de Gruyter.

Longobardi, Giuseppe. 1994. Reference and proper names. Linguistic Inquiry 25(4): 609-665.

Moulton, Keir. 2009. Natural selection and the syntax of clausal complementation. Doctoral dissertation, University of Massachusetts, Amherst.

Müller, Gereon. 1995. A-bar syntax: A study in movement types. Berlin: Mouton de Gruyter.

Müller, Gereon. 1998. Incomplete category fronting: A derivational approach to remnant movement in German, Studies in Natural Language and Linguistic Theory, vol. 42. Dordrecht: Kluwer.

Müller, Gereon. 2010. On deriving CED effects from the PIC. Linguistic Inquiry 41(1): 35-82.

Oishi, Masayuki. 2015. The hunt for a label. In Untiring pursuit of better alternatives, ed. Hiroki Egashira, Hisatsugu Kitahara, Kazuo Nakazawa, Tadao Nomura, Masayuki Oishi, Akira Saizen, and Motoko Suzuki, 322-334. Tokyo: Kaitakusha.

Ott, Dennis. 2011. Local instability: The syntax of split topics. Doctoral dissertation, Harvard University.

Pafel, Jürgen. 1996. Die synaktische und semantische Struktur von was für-phrasen [The syntactic and semantic structure of was-für-phrases]. Linguistische Berichte 161: 37-67.

Prince, Ellen F. 1981. Toward a taxonomy of given/new information. In Radical pragmatics, ed. Peter Cole, 223-255. New York: Academic Press.

Pustejovsky, James. 1995. The Generative Lexicon. Cambridge: MIT Press.

Ross, John. 1967. Constraints on Variables in Syntax. Doctoral dissertation, MIT.

Simonenko, Alexandra. 2015. Semantics of DP Islands: the case of questions. Journal of Semantics 33(4): 661-702.

Van Eynde, Frank. 2006. NP-internal agreement and the structure of the noun phrase. Journal of Linguistics 42(1): 139-186. 